Vol.59: e16160139, January-December 2016 http://dx.doi.org/10.1590/1678-4324-2016160139 ISSN 1678-4324 Online Edition
BRAZILIAN ARCHIVES OF BIOLOGY AND TECHNOLOGY

AN INTERNATIONAL JOURNAL

\title{
Rosemary and Pitanga Aqueous Leaf Extracts On Beef Patties Stability under Cold Storage
}

\author{
Flávia Carolina Vargas ${ }^{1}$; Lucas Arantes-Pereira ${ }^{2}$; Patrícia Argemira da Costa ${ }^{1}$; Mariza \\ Pires de Melo'; Paulo José do Amaral Sobral' ${ }^{1}$. \\ ${ }^{I}$ Faculdade de Zootecnia e Engenharia de Alimentos, Universidade de São Paulo, Pirassununga - SP, \\ Brazil. ${ }^{2}$ Instituto Federal de Educação, Ciência e Tecnologia do Triangulo Mineiro, Uberaba - MG, Brazil.
}

\begin{abstract}
Because processing and storage conditions affect several beef quality attributes, the food industry uses a variety of synthetic antioxidants. However, some synthetic antioxidants have been questioned regarding its safety, and thus the interest in using natural antioxidants in food products is increasing. This paper aimed at assessing leaf aqueous extracts of Rosemary (Rosmarinus officinalis Linnaeus) and Pitanga (Eugenia uniflora Linnaeus) as antioxidants in beef cold storage. After $48 \mathrm{~h}$ storage, patties added of Rosemary leaf extracts showed increased pH. Patties added of Pitanga extracts had the lowest a* color values. Oxymyoglobin levels were significantly higher for Negative control, than for Pitanga treatment. The 10\% extract addition increased lipid oxidation of beef patties. Correlation coefficients between lipid and myoglobin oxidations were all above 0.85. Pitanga leaf extracts negatively influenced beef color, probably because of its higher chlorophyll content. Lipid oxidation of beef patties was increased with the addition of leaf extracts. The inclusion of 10\% leaf extract into beef patties seems not suitable, because it may enhance the amount of prooxidant compounds, as well as the amount of substances capable of reacting with lipid secondary products. Correlations between lipid and myoglobin oxidations demonstrated strong relationship.
\end{abstract}

Key words: antioxidant, myoglobin, color, oxidation, lipid.

*Authors for correspondence: fla_vargas@yahoo.com 


\section{INTRODUCTION}

Fresh beef is very sensitive to processing and storage temperatures, presence of oxygen, water, light, enzymatic, and microbiological activity. ${ }^{1}$ These factors can cause undesirable changes in beef quality attributes such as color, odor, texture, and nutritional composition.

One of the most important attributes of beef is color that greatly influences purchase, since consumers associate this attribute to quality. ${ }^{2,3}$ The pigment responsible for the bright red color of beef is myoglobin, that when oxidized, causes meat rejection at the time of purchase. Moreover, the oxidation of myoglobin is also connected to the rancidity process, ${ }^{2}$ potentially catalyzing the oxidation of lipids, and thereby generating toxic compounds and off-flavor.

The use of antioxidants by the food industry happens through a variety of synthetic antioxidants, which has been questioned because of the carcinogenicity of some of them. ${ }^{4}$ Therefore, there is increased interest in replacing synthetic by natural antioxidants, as well as in intensifying the search for plant materials containing antioxidant compounds. ${ }^{5}$ The antioxidant activity of spices like rosemary, oregano, cinnamon and clove is widely documented in the literature. ${ }^{6-8}$ On the other hand, research concerning the characterization and antioxidant potential of Brazilian native plant species, as Pitanga are still very scarce.

In this sense, this paper aimed at characterizing and assessing leaf aqueous extracts of Pitanga (Eugenia uniflora Linnaeus), a Brazilian native plant species, and Rosemary (Rosmarinus officinalis Linnaeus), a well-documented plant species as antioxidants, to prevent lipid and myoglobin oxidation and enhance raw beef cold storage stability.

\section{MATERIALS AND METHODS}

\section{PLANT MATERIAL}

Leaves of two edible plant regularly consumed in Brazil, Pitanga (E. uniflora) and Rosemary ( $R$. officinalis), were collected in Pirassununga $\left(21^{\circ}\right.$ $\left.59^{\prime} 46^{\prime \prime} \mathrm{S}, 47^{\circ} 25^{\prime} 36^{\prime \prime} \mathrm{W}\right)$, São Paulo, Brazil. Leaves were rinsed and dried in an air circulating oven (MA035/5, MARCONI, Piracicaba, Brazil) at $65{ }^{\circ} \mathrm{C}$ for 72 hours. Leaves were then grinded and sieved (48 mesh) in order to have uniform particle size.

\section{PROXIMATE COMPOSITION ANALYSES OF LEAVES}

Proximate Composition analyses were performed in duplicates according to the methodologies described by $\mathrm{AOAC}^{9}$ to know the main components of the target materials. Leaves were dried in air circulating oven at $105{ }^{\circ} \mathrm{C}$ for $12 \mathrm{~h}$ for moisture content determinations. Afterwards, the remaining material was placed in a muffle furnace at $550{ }^{\circ} \mathrm{C}$ for $24 \mathrm{~h}$ for the determination of ash content. Crude fiber content was determined by acid followed by basic digestion. Lipids were extracted using a Soxhlet apparatus for $6 \mathrm{~h}$ and crude protein content was determined by Kjeldahl method with conversion factor 6.25 to convert total nitrogen into crude protein. In order to obtain the amount of nitrogen-free extract, which consists mainly of carbohydrates, the contents of crude fiber, crude protein, lipids, and ashes were subtracted from 100.

\section{CHLOROPHYLL AND CAROTENOID DETERMINATIONS OF LEAVES}

Total chlorophyll, chlorophyll a, chlorophyll b, and total carotenoid content determinations were performed spectophotometrically, based on the methodologies proposed by Yang et al. ${ }^{10}$ with slight modifications. $10 \mathrm{~g}$ of each leave were added in $10 \mathrm{~mL}$ of $80 \%(\mathrm{v} / \mathrm{v})$ acetone:water solution. Pigments were extracted with UltraTurrax (Janke and Kunkel, IKA-Labortechnik, Gmbh and Co., Staufen, Germany) for $5 \mathrm{~s}$ and centrifuged at a speed of $1,500 \mathrm{~g}$ for $5 \mathrm{~min}$ (Thermo IEC, Centra-GP8R, Refrigerated Benchtop Centrifuge, USA). After discharging the formed pellets, absorbances were read at 663.6, 646.6, and $440.5 \mathrm{~nm}$ in a spectrophotometer (UVVIS lambda 35, Perkin Elmer, Needhan heights, MA, USA) to determine chlorophyll a, chlorophyll b, total chlorophyll, and total carotenoid contents, respectively, by calculations using the following Eq. 1, 2, 3, and 4:

Chl a $=12.25 \mathrm{ABS}_{663.6}-2.55 \mathrm{ABS}_{646.6}(1)$
$\mathrm{Chl} \mathrm{b}=20.31 \mathrm{ABS}_{646.6}-4.91 \mathrm{ABS}_{663.6}(2)$
Chl total $=17.76 \mathrm{ABS}_{646.6}+7.34 \mathrm{ABS}_{663.6}(3)$
$\mathrm{Car}=4.69 \mathrm{ABS}_{440.5}-0.267 \mathrm{Chl}$ total $(4)$ 
Where: Chl a is the amount of chlorophyll a, Chl b is the amount of chlorophyll b, Chl total is the amount of total chlorophyll, Car is the amount of total carotenoids; and ABS663.6, ABS646.6, and ABS440.5 are the absorbance values obtained at wavelengths 663.6, 646.6 and $440.5 \mathrm{~nm}$, respectively.

\section{EXTRACTS PREPARATION}

Extracts preparation followed the methodology described by Delgado-Adámez et al. $^{11}$ with modifications. Extracts were prepared at 1:10 $(\mathrm{w} / \mathrm{v})$ with distilled water in an ultra-thermostat water bath (MA184/BX, Marconi Marconi Equipamentos Para Laboratórios Ltda, São Paulo, Brazil) at $90{ }^{\circ} \mathrm{C}$ for $30 \mathrm{~min}$ with the aid of a mechanical stirrer (TE 039, TECNAL Equipamentos para Laboratórios Ltda, São Paulo, Brazil). Extracts were cooled at room temperature in a temperature controlled laboratory in dark conditions and were filter afterwards with filter paper Whatman \#1 (Whatman International Ltd, Maidstone, England).

\section{PHYSICOCHEMICAL MEASUREMENTS OF EXTRACTS}

For instrumental $\mathrm{pH}$ measurements, a portable pHmeter (PG1400, Ind e Com. Eletrônica Gehaka Ltda., São Paulo, Brazil) was used. Instrumental color of aqueous extracts was determined using a portable colorimeter (MiniScan EZ 4500L Hunter Associates Laboratory, West Virginia, USA), $10^{\circ}$ observation angle, illuminant D65, and the CIE Lab color scale. The soluble solid content $\left({ }^{\circ} \mathrm{BX}\right)$ of the extracts were measured with an abbe manual refractometer. All measurements were done in triplicates.

\section{BEEF PATTIES PREPARATION AND STORAGE}

Ground beef from a Brazilian traditional cut named "patinho", similar to the American knuckle, which comprises the muscles Vastus intermedius, Vastus lateralis, Vastus medialis and Rectus femoris, was purchased from a local market. Beef patties $(50 \mathrm{~g})$ were prepared with manual homogenization and shaped on a hamburger patty mold. After molding, patties were placed on polypropylene trays $(n=9$, each treatment), covered with polyvinyl chloride (PVC) film and stored under artificial light conditions at $4{ }^{\circ} \mathrm{C}$ for 4 days in a display case. Treatments were: ground beef without extracts (Negative control), ground beef with $10 \% \quad(1: 10, \quad \mathrm{v} / \mathrm{w})$ Rosemary extract
(Rosemary), and ground beef with 10\% (1:10, v/w) Pitanga extract (Pitanga). Since higher soluble solid content of extracts may indicate greater quantities of antioxidant substances such as phenolic compounds, corrections were made prior to meat incorporation with the addition of distilled water, so that extracts could have the same soluble solid content. Samples were taken on days 0, 2, and 4 of storage. During storage, $\mathrm{pH}$ and color measurements were performed according to the same methodologies described for the extracts.

\section{MYOGLOBIN REDOX ANALYSES OF BEEF PATTIES}

Myoglobin redox species (metmyoglobin, deoxymyoglobin, and oxymyoglobin) were analyzed according to Tang et al. ${ }^{12}$ Beef samples were precisely weighed $(2.00 \mathrm{~g})$, added of $20 \mathrm{~mL}$ phosphate buffer solution $(\mathrm{pH}$ 6.8), and homogenized for $30 \mathrm{~s}$ with a digital Ultra-Turrax (Janke and Kunkel, IKA-Labortechnik, Gmbh and Co., Staufen, Germany). After $1 \mathrm{~h}$ rest, samples were centrifuged at 4,000 g (Thermo IEC CentraGP8R Refrigerated Benchtop Centrifuge, Needhan heights, MA, USA) for $30 \mathrm{~min}$ and the supernatant was filtered using filter paper Whatman \#1 (Whatman International Ltd, Maidstone, England). Buffer solution was added to complete $25 \mathrm{~mL}$ prior to a second filtration in a membrane filter (GSWP02500, Merck Millipore Corporation, Darmstadt, Germany) with $0.22 \mu \mathrm{m}$ pore size and $0.25 \mathrm{~mm}$ diameter. Absorbances were read at 503, 252, 557, and $582 \mathrm{~nm}$ in a spectrophotometer (UV-VIS lambda 35, Perkin Elmer, Needhan heights, MA, USA). Samples were kept under dark and refrigerated conditions during all procedures. Results of deoxymyoglobin, oxymyoglobin and metmyoglobin (g.g total myoglobin ${ }^{-1}$ ) were calculated with Eq. 5, 6, and 7, respectively. Myoglobin concentration was considered as the sum of the three myoglobin redox species.

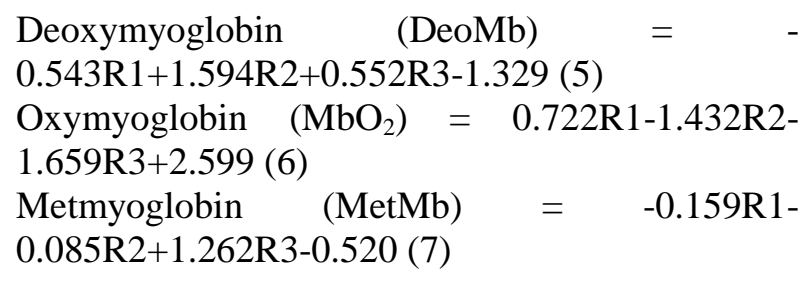

Where: R1, R2 and R3 are the ratios of the absorbances 582/525, 557/525, and 503/525, respectively. 


\section{LIPID OXIDATION ANALYSES OF BEEF PATTIES}

Lipid oxidation was assessed by the determination of thiobarbituric acid reactive substances (TBARS), with malondialdehyde (MDA) as the main lipid peroxidation product, according to the methodologies described by Sorensen and Jorgensen ${ }^{13}$ and Vyncke. ${ }^{14,15}$ Beef samples were frozen in liquid nitrogen up to the moment of the assays. Meat samples were kept in ice to allow slow thawing. After thaw, $5 \mathrm{mg}$ of each patty were weighed in duplicates. Samples were added of trichloroacetic acid $(15 \mathrm{~mL})$ and homogenized in Ultra-Turrax (Janke and Kunkel, IKALabortechnik, Gmbh and Co., Staufen, Germany) for $60 \mathrm{~s}$. Homogenized solutions were filtered in filter paper Whatman \#1 (Wathman International Ltd, Maidstone, England). After filtration, $3 \mathrm{~mL}$ of 2-tiobarbituric acid were added to samples, which were incubated for $40 \mathrm{~min}$ in an ultra-thermostat water bath (MA184/BX, Marconi Marconi Equipamentos Para Laboratórios Ltda, São Paulo, Brazil) at $100{ }^{\circ} \mathrm{C}$. In order to stop chemical reactions, tubes containing samples were cooled in ice. Absorbances were read at $532 \mathrm{~nm}$ and $600 \mathrm{~nm}$ using a spectrophotometer (UV-VIS lambda 35, Perkin Elmer, Needhan heights, MA, USA). Results ( $\mu \mathrm{g} \mathrm{MDA} \mathrm{g}^{-1}$ ) were calculated with Eq. 8.

TBARS $\left(\mu \mathrm{g} \mathrm{MDA} \mathrm{kg}^{-1}\right)=(\mathrm{C} \times \mathrm{Va} \mathrm{x}$ VTCA $) /(\mathrm{Vs} \mathrm{x}$ W) (8)

Where: $\mathrm{C}$ is the sample concentration, $\mathrm{Va}$ is the volume of total assay, VTCA is the volume of TCA added to samples, Vs is the sample volume, $\mathrm{W}$ is the sample weight.

\section{STATISTICAL ANALYSES}

All the data were submitted to ANOVA. Significant differences were analyzed by Tukey's test at 5\% by SAS software (SAS Institute Inc., Cary, USA) version 9.2.

Leaf and extracts characterization data were analyzed in a completely randomized design. Beef preservation assay data were analyzed in a $3 \times 3$ completely randomized factorial design in which treatments (Rosemary or Pitanga extract addition/absence) and time (0, 2, and 4 days) were the factors, and patties were the experimental units. Pearson's correlation was performed to assess the relationship between lipid and myoglobin oxidations.

All assays were carried out in triplicates and results were expressed as Mean \pm Standard Deviation.

\section{RESULTS AND DISCUSSION \\ PROXIMATE COMPOSITION, CHLOROPHYLL AND CAROTENOID CONTENT OF LEAVES}

Proximate composition of dried leaves showed significant differences for ash, crude protein and lipid content, however no difference was found for dry matter, crude fiber, and nitrogen-free extract content of Rosemary and Pitanga leaves (Table 1). It is important to mention that the nitrogen-free extract was relatively high; that this extract is composed mainly by carbohydrates, and that polyphenols may compose such extract, as well. Ash and crude protein contents in Pitanga leaves were greater than in Rosemary leaves, whereas lipids in Rosemary samples were 3-fold higher than in Pitanga leaves (Table 1). The superiority of Rosemary leaves lipid content indicates that the leaves of this plant may produce more essential oil than Pitanga ones. Essential oil of Rosemary has shown antioxidant properties; ${ }^{8}$ nevertheless, this nonpolar substance is not necessarily available in aqueous extracts.

These results (Table 1) are in agreement with the ones obtained by Polat et al. ${ }^{16}$ for fresh leaves of Rosemary regarding dry matter $\left(940 \mathrm{~g} \mathrm{~kg}^{-1}\right)$, ash $\left(79.5 \mathrm{~g} \mathrm{~kg}^{-1}\right)$, and lipid content $\left(160.8 \mathrm{~g} \mathrm{~kg}^{-1}\right)$. For the other parameters, these authors describe different values (55 crude protein, 252.4 crude fiber, and $394 \mathrm{~g} \mathrm{~kg}^{-1}$ nitrogen-free extract), what may be due to differences in plants' habitat and growth stage, as well as in period of the year and time of harvesting.

Chlorophyll a, chlorophyll $\mathrm{b}$ and total chlorophyll content of Pitanga dried leaves were greater $(p<0.05)$ than the content of Rosemary leaves (Table 1). On the other hand, total carotenoid content did not differ $(p>0.05)$ between samples (Table 1). Kim et al. ${ }^{17}$ analyzed chlorophyll and carotenoid contents of ten edible plant extracts and observed chlorophyll a content ranging from 0.05 to $0.44 \mathrm{~g} \mathrm{~kg}^{-1}$ Dry Matter, which is below the contents found in the current study for Rosemary and Pitanga leaves. 
Table 1. Proximate composition, chlorophyll ( $\mathrm{a}, \mathrm{b}$, and total) and total carotenoid content $\left(\mathrm{g} \mathrm{kg}^{-1}\right.$ Dry Matter) of dried leaves, and physicochemical parameters of extracts ( $\mathrm{pH},{ }^{\circ} \mathrm{BX}$, and CIE Lab parameters).

\begin{tabular}{lll}
\hline \multirow{2}{*}{ Parameters } & \multicolumn{2}{l}{ Samples } \\
\cline { 2 - 3 } & Rosemary & Pitanga \\
\hline Dry Matter* & $924 \pm 0^{\mathrm{a}}$ & $926.2 \pm 2^{\mathrm{a}}$ \\
Ash Content & $74.2 \pm 0^{\mathrm{b}}$ & $89.2 \pm 1^{\mathrm{a}}$ \\
Crude Protein & $104.8 \pm 2^{\mathrm{b}}$ & $125.0 \pm 6^{\mathrm{a}}$ \\
Crude Fiber & $113.4 \pm 2^{\mathrm{a}}$ & $135 \pm 7^{\mathrm{a}}$ \\
Lipid Content & $121.0 \pm 1^{\mathrm{a}}$ & $42.2 \pm 5^{\mathrm{b}}$ \\
Nitrogen-Free Extract & $532.6 \pm 0^{\mathrm{a}}$ & $534.8 \pm 2^{\mathrm{a}}$ \\
Chlorophyll a & $1.10 \pm 0.13^{\mathrm{b}}$ & $1.36 \pm 0.12^{\mathrm{a}}$ \\
Chlorophyll b & $0.48 \pm 0.06^{\mathrm{b}}$ & $0.65 \pm 0.08^{\mathrm{a}}$ \\
Total Chlorophyll & $1.58 \pm 0.2^{\mathrm{b}}$ & $2.01 \pm 0.02^{\mathrm{a}}$ \\
Carotenoids & $0.36 \pm 0.05^{\mathrm{a}}$ & $0.35 \pm 0^{\mathrm{a}}$ \\
pH & $5.7 \pm 0.1^{\mathrm{a}}$ & $4.5 \pm 0.1^{\mathrm{b}}$ \\
${ }^{\circ}$ BX & $2.6 \pm 0.4^{\mathrm{b}}$ & $3.6 \pm 0.2^{\mathrm{a}}$ \\
$\mathbf{L}^{*}$ & $21.80 \pm 0.3^{\mathrm{b}}$ & $30.43 \pm 0.3^{\mathrm{a}}$ \\
a $^{*}$ & $25.44 \pm 0.1^{\mathrm{a}}$ & $12.11 \pm 0.9^{\mathrm{b}}$ \\
b $^{*}$ & $35.76 \pm 0.5^{\mathrm{b}}$ & $41.29 \pm 0.7^{\mathrm{a}}$ \\
\hline
\end{tabular}

*Dry Matter on Wet Basis. ${ }^{a-b}$ means \pm standard deviation with the same letter in a row are not significantly different by Tukey's test $(\mathrm{p}<0.05)$.

Chlorophyll is a sensitizer molecule that can lead to the formation of reactive oxygen species ${ }^{18}$, which in turn can oxidize important molecules in biological systems. ${ }^{19}$ In this sense, regardless of the target plants antioxidant properties, Pitanga leaves are more likely to cause lipid oxidation in beef patties stored under artificial light conditions, because of its higher chlorophyll content.

Carotenoids are excellent antioxidants because they have the ability to quench singlet oxygen, release the energy acquired during this reaction, and return to their original state. ${ }^{18}$ The total carotenoid contents found in the present are even superior to the maximum range $(0.18 \mathrm{~g} \mathrm{~kg}$ Dry Matter) found by Kim et al., ${ }^{17}$ suggesting better antioxidant potential.

\section{PHYSICOCHEMICAL PARAMETERS OF EXTRACTS}

Table 1 shows results for $\mathrm{pH}$, soluble solid content and CIE Lab color parameters of Rosemary and Pitanga aqueous extracts. $\mathrm{pH}$ values of Rosemary extracts were significantly higher than $\mathrm{pH}$ values of Pitanga extracts, as well as the intensity of redness $\left(\mathrm{a}^{*}\right)$. Whereas soluble solid content, and color parameters $\mathrm{L}^{*}$ and $\mathrm{b}^{*}$ were significantly higher $(p<0.05)$ for Pitanga than for Rosemary extracts (Table 1).
Phenolic acids, present in several herbs and spices, ${ }^{20,21}$ may contribute for the higher acidity found in Pitanga extracts, however further investigations to quantify phenolic and other acid compounds are needed to elucidate that. Regarding color, it is well known that pigments such as chlorophylls, anthocyanins, carotenoids, and myoglobin are responsible for natural food color and that during food processing and storage some chemical and microbiological reactions may cause food color changes. Moreover, food color, as a consequence of its pigments, is strongly influenced by $\mathrm{pH}$. According to Andrés-Bello et al., ${ }^{22}$ the reddish and greenish colors of foods, which are normally associated to carotenoid and chlorophyll, are affected by low $\mathrm{pH}$ values. In the current research the total carotenoid content of extracts did not differ between samples, what allows the inference that these compounds were not affected by $\mathrm{pH}$. Adversely, attention must be drawn to the lower red intensity $\left(a^{*}\right)$ of Pitanga extracts, which may have been influenced by the chlorophyll content of this species' dried leaves, and for its lower $\mathrm{pH}$ value. Even though these green pigments are greatly degraded with thermal process ${ }^{23}$, the superior total chlorophyll content of Pitanga leaves may have contributed for this difference in extracts color. 


\section{pH AND COLOR VARIATION OF BEEF PATTIES}

Significant interaction ( $>0.05)$ between factors (treatment $\mathrm{x}$ time) have been found for $\mathrm{pH}$ values (Table 2), which were similar among treatments during the first 48 hours. After that period, only Rosemary added patties had $\mathrm{pH}$ values increased markedly until the end of the storage period (Fig.
1A). A suitable explanation for that is the occurrence of microbial growth in these samples. The ammonia production, as a result of amino acid metabolism perfomed by many bacteria, is the main cause of $\mathrm{pH}$ increase in chilled meat products. ${ }^{24}$ Nonetheless, microbial analyses of beef patties, as well as the antimicrobial activity of extracts are required for this confirmation.

Table 2. Summary of analysis of variance from the completely randomized factorial design.

\begin{tabular}{|c|c|c|c|}
\hline & \multicolumn{3}{|l|}{$\underline{\operatorname{Pr}>F}$} \\
\hline & $\overline{\text { Treatment }}$ & Time & Interaction \\
\hline TBARS $\dagger$ & $0.021^{*}$ & $>0.001 * *$ & $>0.001 * *$ \\
\hline $\mathbf{L}^{*}$ & $0.001 * *$ & $>0.001 * *$ & 0.4034 \\
\hline $\mathbf{a}^{*}$ & $0.001 * *$ & $>0.001 * *$ & 0.0754 \\
\hline b* & 0.2287 & $>0.001 * *$ & 0.1211 \\
\hline pH & $>0.001 * *$ & $>0.001 * *$ & $0.0002 * *$ \\
\hline Deoxymyoglobin & $0.0263 *$ & $0.0231 *$ & 0.0974 \\
\hline Oxymyoglobin & $0.0044 * *$ & $0.0009 * *$ & 0.1963 \\
\hline Metmyoglobin & $0.0024 * *$ & $0.0008 * *$ & 0.342 \\
\hline
\end{tabular}

$†$ TBARS - Lipid oxidation as Thiobarbituric reactive substances. * $\mathrm{p}<0.05$, ** $<0.01$ by F Test (ANOVA).

No interaction between factors have been found regarding color parameters $\mathrm{L}^{*}, \mathrm{a}^{*}$, and $\mathrm{b}^{*}$ (Table 2); however variations along storage time (Fig. 1B) and among treatments (Table 3 ) have been significant $(\mathrm{p}<0.05)$. Throughout time, all parameters showed slight descendent tendency (Fig. 1B), as expected for retail conditions. Parameter $\mathrm{a}^{*}$ of color has shown a stronger decreasing behavior, what is of greater importance because consumers associate redness to freshness. ${ }^{25}$ Since no difference was found among treatments, it is possible to state that the inclusion of $10 \%$ aqueous extracts of Rosemary and Pitanga leaves into raw beef patties was not able to maintain color attribute during cold storage. This result is in agreement with several studies, ${ }^{17,26-28}$ with no observed color stability after the inclusion of plant extracts in beef patties. Nevertheless, some research ${ }^{17,27,28}$ reported lower overall $a^{*}$ values for the Negative control samples when compared to extract-added patties. Adversely, in our studies patties added of Pitanga extracts showed the lowest $\mathrm{a}^{*}$ values when compared to Negative control or to samples added of Rosemary extracts (Table 3). Parameters L* (lightness) of color was higher for Pitanga treatment (Table 3), suggesting a possible effect of extract's color (Table 1).

Besides that, as reported by Kim et al., ${ }^{27}$ extracts' color may have influenced beef patties color in our experiments. Extracts from Rosemary leaves were 2 fold redder than extracts from Pitanga leaves (Table 1), occasioning the patties added with Rosemary leaf extract to be redder than patties added of Pitanga extracts.

\section{MYOGLOBIN REDOX SPECIES OF BEEF PATTIES}

As what has been found for the color parameter, no interaction between factors have been observed regarding myoglobin redox species; variations along storage time and among treatments have been significant, though (Table 2). As expected, oxymyoglobin and metmyoglobin levels were inversely proportional throughout cold storage period, with metmyoglobin increasing after $24 \mathrm{~h}$, approximately (Fig. 1C). After 48 h, variations in myoglobin redox species did not seem to occur relevantly.

Mean deoxymyoglobin levels were lower for Negative control patties than for Rosemary and Pitanga added patties (Table 3); however, the totality percentage of this species was very low when compared to the other two, at around 10\%, with little interference on beef color. Oxymyoglobin levels, which are responsible for the desired bright red color of raw beef, were significantly higher for Negative control (Table 3), than for Pitanga treated patties. Rosemary oxymyoglobin values were between Pitanga and 
Negative control, with no significant difference (Table 3). Metmyoglobin, the oxidized myoglobin species related to the brownish color of oxidized beef, ${ }^{29}$ showed the greatest mean values for treatment Pitanga (Table 3). This results suggest that the inclusion of Pitanga leaf aqueous extracts into raw beef patties was not capable of protecting myoglobin oxidation, which is in agreement with the results of parameter $a^{*}$ of color of beef patties (Table 3).

Table 3. Mean values of CIE Lab color parameters and myoglobin redox species ( $\mathrm{g} \mathrm{g}^{-1}$ total myoglobin) of beef patties within treatments.

\begin{tabular}{|c|c|c|c|}
\hline \multirow{2}{*}{ Parameters } & \multicolumn{3}{|l|}{ Treatments } \\
\hline & Negative control & Rosemary & Pitanga \\
\hline $\mathbf{L}^{*}$ & $42.51 \pm 2.4^{\mathrm{b}}$ & $43.13 \pm 2.1^{b}$ & $44.75 \pm 2.0^{\mathrm{a}}$ \\
\hline $\mathbf{a}^{*}$ & $14.14 \pm 4.5^{\mathrm{a}}$ & $13.51 \pm 2.9^{\mathrm{a}}$ & $12.05 \pm 3.9^{\mathrm{b}}$ \\
\hline b* & $15.78 \pm 2.4^{\mathrm{a}}$ & $16.12 \pm 1.8^{\mathrm{a}}$ & $16.42 \pm 1.5^{\mathrm{a}}$ \\
\hline Deoxymyoglobin & $0.09 \pm 0.03^{\mathrm{b}}$ & $0.16 \pm 0.07^{\mathrm{a}}$ & $0.12 \pm 0.04^{\mathrm{ab}}$ \\
\hline Oxymyoglobin & $0.58 \pm 0.09^{\mathrm{a}}$ & $0.42 \pm 0.2^{\mathrm{ab}}$ & $0.32 \pm 0.22^{\mathrm{b}}$ \\
\hline Metmyoglobin & $0.33 \pm 0.09^{b}$ & $0.42 \pm 0.13^{\mathrm{b}}$ & $0.56 \pm 0.19^{\mathrm{a}}$ \\
\hline
\end{tabular}

${ }^{a-b}$ means \pm standard deviation with the same letter in a row are not significantly different by Tukey's test $(p<0.05)$.

Other than that, considering that leaves from Pitanga showed greater chlorophyll content (Table 1), and that patties treated with Pitanga extracts suffered stronger myoglobin oxidation than the other patties, it can be inferred that chlorophyll participated in the oxidation process of myoglobin.

\section{LIPID OXIDATION OF BEEF PATTIES}

Interaction between factors (plant and time) has been found for lipid oxidation of raw beef patties (Table 2). Figure 1D depicts the variations in mean TBARS values ( $\mu \mathrm{g}$ MDA kg-1) of beef patty during cold storage.

As it can be seen from Figure 1D, the addition of $10 \%(1: 10, \mathrm{w} / \mathrm{v})$ plant extracts has clearly influenced lipid oxidation of raw beef patties. Results from treatments Rosemary and Pitanga were greater than results from Negative control at $48 \mathrm{~h}$ storage, suggesting that instead of protection, an inverse effect occurred. This probably happened because of the high inclusion rate of crude extracts into patties, possibly providing high concentrations of prooxidant compounds, such as chlorophyll, $\mathrm{Fe}$ or $\mathrm{Cu}$. According to Decker, ${ }^{30}$ multicomponent antioxidant systems, as the target leaf extracts, are effective in preventing oxidation because of the interaction among different types of antioxidants, such as metal chelators and different free radical scavengers. However, this author also states that the oxidative stability of food depends on the concentration of prooxidant and antioxidant substances present in a system, which must be balanced.

Interestingly, lipid oxidation of Rosemary and Pitanga added patties showed a decreasing tendency after $48 \mathrm{~h}$ storage, while TBARS values of Negative control samples steadily increased during storage period (Fig. 1D). The diminishing TBARS values of extract-added patties can be explained by the fact that aldehydes (the lipid oxidation products measured in the assay) are very reactive $^{31}$ and can interact with many other substances in food or biological tissues. ${ }^{32}$ In our experiment, compounds from leaf extracts, such as primary amine groups from proteins, may have reacted with aldehydes from lipid oxidation. This interaction may have occurred because of the relatively high (10\%) level of extracts inclusion into patties. Chaijan ${ }^{33}$ and Kamal-Eldin and Pokony $^{32}$ also reported that aldehydes could react with proteins, amino acids and peptides, affecting protein functionality, altering meat color stability, and hindering the determination of these lipid oxidation products by ordinary analytical methods. 

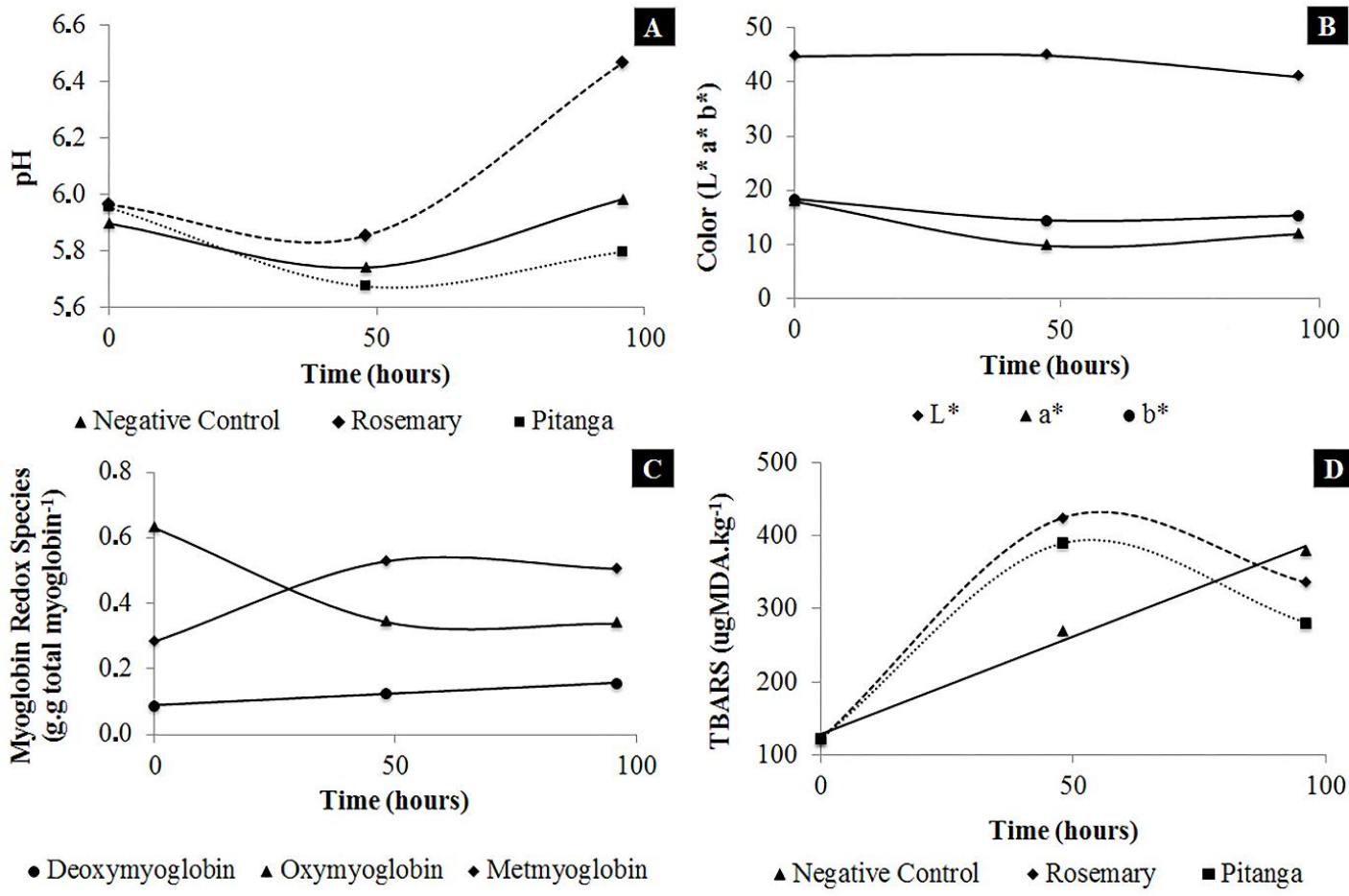

Figure 1. Variation of pH (A), CIE Lab color parameters (B), myoglobin redox species (C), and lipid oxidation as TBARS (D) of beef patties throughout cold storage period.

\section{LIPID AND MYOGLOBIN OXIDATION CORRELATIONS}

The relationship between lipid and myoglobin oxidation was assessed by Pearson's correlation coefficients, with figures of $0.86,0.98$, and 0.95 for Negative control, Rosemary, and Pitanga treatments, respectively. As it can be seen, all the three treatments showed correlation coefficients above 0.85 , which can be considered high. These correlation coefficients clearly reinforce the existence of a relationship between the two oxidation types, as it has been reported and revised by a variety of authors. ${ }^{2,29,33-36}$ Even though the mechanisms by which these two types of oxidation interact are still not completely elucidated, some authors have proposed possible means of interaction. Min et al. ${ }^{35}$ suggested that the free ionic iron catalyzes lipid oxidation. Lund et al., ${ }^{36}$ on the other hand, report that the accumulation of hypervalent myoglobin species, generated after the depletion of reducing enzymes in biological systems, may be responsible for initiating lipid oxidation.

\section{CONCLUSIONS}

Within our experimental conditions, Pitanga leaf extracts have negatively influenced beef color (redness and metmyoglobin formation), probably because of its high chlorophyll content, suggesting that this pigment is more likely to affect myoglobin oxidation. Rosemary leaf extracts promoted better color and myoglobin stability of raw beef patties than Pitanga leaf extracts. Nonetheless, lipid oxidation of beef patties was increased with the addition of both leaf extracts. Correlations between lipid and myoglobin oxidations demonstrated strong relationship.

The inclusion of $10 \%(1: 10, \mathrm{v} / \mathrm{w})$ aqueous leaf extract into beef patties seems not suitable, because it may enhance the amount of prooxidant compounds that promote lipid oxidation and the amount of substances capable of reacting with lipid secondary products, hindering their detection by common analytical methods. This inclusion rate may have also influenced patties' color. Therefore, lower inclusion levels of aqueous leaf extracts should be tested in order to allow lipid and myoglobin protection, as well as effective MDA detection. 
Microbiological analyses should be performed in future studies, so that the antimicrobial activity of extracts can be tested during beef cold storage. Moreover, the role of chlorophyll as prooxidant on myoglobin oxidation process needs further investigation.

\section{ACKNOWLEDGMENTS}

Authors gratefully thank Faculdade de Zootecnia e Engenharia de Alimentos from Universidade de São Paulo for allowing the experiments, and also Coordenação de Aperfeiçoamento de Pessoal de Nível Superior (CAPES) and Conselho Nacional de Desenvolvimento Científico e Tecnológico (CNPq) for the first author's fellowship.

\section{REFERENCES}

1. Zhou GH, Xu XL and Liu Y. Preservation technologies for fresh meat - a review. Meat Sci. 2010; 86: 11928.

2. Faustman C, Sun Q, Mancini R, Suman SP. Myoglobin and lipid oxidation interactions: mechanistic bases and control. Meat Sci. 2010; 86: 86-94.

3. Troy DJ, Kerry JP. Consumer perception and the role of science in the meat industry. Meat Sci. 2010; 86: 214-226.

4. Gharavi N, Haggarty $\mathrm{S}$ and El-Kadi AOS. Chemoprotective and carcinogenic effects of tertbutylhydroquinone and its metabolites. Curr Drug Metab. 2007; 8: 1-7.

5. Argoti JC, Salido S, Linares-Palomino PJ, Ramírez B, Insuasty B, Altarejos J. Antioxidant activity and free radical-scavenging capacity of a selection of wildgrowing Colombian plants. J Sci Food Agric. 2011; 91: 2399-2406.

6. Fasseas MK, Mountzouris KC, Tarantilis PA, Polissiou M, Zervas G. Antioxidant activity in meat treated with oregano and sage essential oils. Food Chem. 2008; 106: 1188-1194.

7. Kong B, Zhang H, Xiong YL. Antioxidant activity of spice extracts in a liposome system and in cooked pork patties and the possible mode of action. Meat Sci. 2010; 85: 772-778.

8. Özcan MM, Arslan D. Antioxidant effect of essential oils of rosemary, clove and cinnamon on hazelnut and poppy oils. Food Chem. 2011; 129: 171-174.

9. AOAC Association of Official Analytical Chemists. Official Methods of Analysis. 18th ed. Gaithersburg: AOAC International; 2005.

10. Yang C-M, Chang K-W, Yin M-H, Huang H-M. Methods for the Determination of the Chlorophylls and their Derivates. Taiwania. 1998; 43: 116-122.

11. Delgado Adámez J, Gamero Samino E, Valdés Sánchez E, González-Gómez D. In vitro estimation of the antibacterial activity and antioxidant capacity of aqueous extracts from grape-seeds (Vitis vinifera L.). Food Control. 2012; 24: 136-141.

12. Tang J, Faustman C, Hoagland TA. Krzywicki revisited: equations for spectrophotometric determination of myoglobin redox forms in aqueous meat extracts. J Food Sci. 2004; 69: 717-720.

13. Sorensen G, Jorgensen SS. A critical examination of some experimental variables in the 2-thiobarbituric acid (TBA) test for lipid oxidation in meat products. Eur Food Res Technol. 1996; 202: 205-210.

14. Vyncke W. Direct determination of thiobarbituric acid value in trichloracetic acid extracts of fish as a measure of oxidative rancidity. Eur J Lipid Sci Tech. 1970; 72: 1084-1087.

15. Vyncke W. Evaluation of direct thiobarbituric acid extraction method for determining oxidative rancidity in mackerel (Scomber scombrus L.). Eur J Lipid Sci Tech. 1975; 77: 239-240.

16. Polat U, Yesilbag D, Eren M. Serum Biochemical Profile of Broiler Chickens Fed Diets Containing Rosemary and Rosemary Volatile Oil. J Biol Environ Sci. 2011; 5: 23-30.

17. Kim S-J, Min SC, Shin H-J, Lee Y-J, Cho AR, Kim $S Y$, et al. Evaluation of the antioxidant activities and nutritional properties of ten edible plant extracts and their application to fresh ground beef. Meat Sci. 2013; 93: 715-722.

18. Krinsky NI. The antioxidant and biological properties of the carotenoids. Ann Ny Acad Sci. 1998; 443-447.

19. Halliwell B, Gutteridge J. Free Radicals in Biology and Medicine. In: Halliwell B and Gutteridge J, editors. New York: Oxford University Press Inc; 2007.

20. Shan B, Cai YZ, Sun M, Corke H. Antioxidant Capacity of 26 Spice Extracts and Characterization of Their Phenolic Constituents. J Agric Food Chem. 2005; 53: 7749-7759.

21. Wojdylo A, Oszmianski J, Czemerys R. Antioxidant activity and phenolic compounds in 32 selected herbs. Food Chem. 2007; 105: 940-949.

22. Andrés-Bello A, García-Segovia P, Martínez-Monzó J. Vacuum frying process of gilthead sea bream (Sparus aurata) fillets. Innov Food Sci Emerg Technol. 2010; 11: 630-636.

23. Van Loey A, Ooms V, Weemaes C, Van den Broeck I, Ludikhuyze L, Indrawati, et al. Thermal and Pressure-Temperature Degradation of Chlorophyll in Broccoli (Brassica oleracea L. italica) Juice: A Kinetic Study. J Agric Food Chem.1998; 46: 52895294.

24. Nychas G-JE, Skandamis PN, Tassou CC, Koutsoumanis KP. Meat spoilage during distribution. Meat Sci. 2008; 78: 77-89.

25. Zakrys-waliwander PI, O'Sullivan MG, Allen P, O'Neill EE, Kerry JP. Investigation of the effects of commercial carcass suspension ( 24 and $48 \mathrm{~h}$ ) on meat quality in high oxygen modified atmosphere packed 
beef steaks during chill storage. Food Res Int. 2010; 43: 277-284.

26. Han J, Rhee KS. Antioxidant properties of selected Oriental non-culinary/nutraceutical herb extracts as evaluated in raw and cooked meat. Meat Sci. 2005; 70: 25-33.

27. Kim S-J, Cho AR, Han J. Antioxidant and antimicrobial activities of leafy green vegetable extracts and their applications to meat product preservation. Food Control. 2013; 29: 112-120.

28. Sánchez-Escalante A, Djenane D, Torrescano G, Beltrán JA, Roncalés P. Antioxidant Action of Borage, Rosemary, Oregano, and Ascorbic Acid in Beef Patties. J Food Sci. 2003; 68: 339-344.

29. Renerre M. Oxidative Process and Myoglobin. In: Decker EC, Faustman C, Lopez-Bote CJ, editors. .Antioxidants in muscle foods. New York: John Wiley \& Sons; 2000. p.113-133.

30. Decker EA. Strategies for manipulating the prooxidative/antioxidative balance of foods to maximize oxidative stability. Trends Food Sci Technol. 1998; 9: 241-248.

31. Pokorný J, Kolakowska A, Bienkiewicz G. Analysis of Interaction Products of Oxidized Lipids with Amino Acids, Proteins, and Carbohydrates. In: Kamal-Eldin A, Pokorný J. Analysis of Lipid Oxidation. Illinois: AOCS Press; 2005.

32. Kamal-Eldin A, Pokorný J. Lipid Oxidation Products and Methods Used for Their Analysis In: KamalEldin A, Pokorný J. Analysis of Lipid Oxidation. Illinois: AOCS Press; 2005. p. 1-7.

33. Chaijan M. Review: Lipid and myoglobin oxidations in muscle foods. Songklanakarin J Sci Technol. 2008; 30: 47-53.

34. Baron CP, Andersen HJ. Myoglobin-Induced Lipid Oxidation. A Review. J Agric Food Chem. 2002; 50: 3887-3897.

35. Min B, Cordray JC, Ahn DU. Effect of $\mathrm{NaCl}$, myoglobin, $\mathrm{Fe}(\mathrm{II})$, and $\mathrm{Fe}(\mathrm{III})$ on lipid oxidation of raw and cooked chicken breast and beef loin. J Agric Food Chem. 2010; 58: 600-605.

36. Lund $\mathrm{MN}$, Heinonen $\mathrm{M}$, Baron $\mathrm{CP}$, Estévez $\mathrm{M}$. Protein oxidation in muscle foods: A review. Molecular Nutrition and Food Research. 2011; 55: 83-95.

Received: January 15, 2016; Accepted: May11, 2016 